Men de pasienter som ønsker det, må gjerne kunne få en papirresept som i dag, gjerne med kode i tillegg. Istedenfor å se alle resepter vil den apotekansatte kun se den resepten som skal effektueres nå.

Det argumenteres for at det er en fordel at apoteket får se hele listen, slik at farmasøytene lettere kan oppdage uheldige kombinasjoner. Men denne kontrollen kan gjøres bedre av de legene som skriver ut preparatene. Jeg har selvfølgelig ingenting imot at min lege får se hele reseptlisten når han skal skrive ut et preparat. Da ivaretas alle personvernhensyn samtidig som man skulle tro at kontrollen blir bedre. Farmasøytene, som jo ikke kjenner pasienten, vil jo uansett bare kunne identifisere uheldige formelle kombinasjoner, og det kan vi jo la datamaskinen ta seg av.

Kai A. Olsen

kai.a.olsen@himolde.no

Kai A. Olsen er professor i informatikk, Høgskolen i Molde og Universitetet i Bergen.

Ingen oppgitte interessekonflikter

Torgeir Bruun Wyller (f. 1960) er overlege ved Geriatrisk avdeling, Oslo universitetssykehus og professor I ved Det medisinske fakultet, Universitetet i Oslo.

Ingen oppgitte interessekonflikter.

\title{
Litteratur
}

1. Lillebø B. Kan antall innleggelser reduseres? Tidsskr Nor Legeforen 2012; 132 2375 .

2. Lillebo B, Dyrstad B, Grimsmo A. Avoidable emergency admissions? Emerg Med J 2012. E-publisert 14.9.

3. Kommunenes plikt til øyeblikkelig hjelp-døgnopphold. Veiledningsmateriell. Oslo: Helsedirektoratet, 2012. www.helsedirektoratet.no/publikasjoner/ kommunenes-plikt-til-oyeblikkelig-hjelp-dognopphold-veiledningsmateriell/ Sider/default.aspx (3.12.2012).

4. Wyller TB. For mange eller for få innleggelser? Tidsskr Nor Legeforen 2010; 130: 1702

5. Wyller TB. Akutte sykehjem - fare for misbruk? Dagens Medisins blogg 20.11.2012. www.dagensmedisin.no/blogg/torgeir-bruun-wyller/ akutte-sykehjem--fare-for-misbruk/ [3.12.2012].

6. Eriksen BO, Førde OH, Kristiansen IS et al. Cost savings and health losses from reducing inappropriate admissions to a department of internal medicine. Int J Technol Assess Health Care 2000; 16: 1147-57.

Publisert som rask respons på nett 3.12. 2012

\section{Usikkert om unødvendige innleggelser}

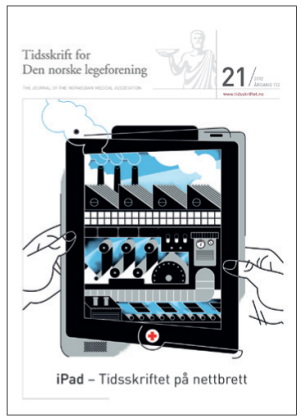

I Tidsskriftet nr. 21/2012 (1) omtales Børge Lillebo og medarbeideres studie om innleggelser som kunne vært unngått (2). Den er politisk svært aktuell, siden Helse- og omsorgsdepartementet som ledd i samhandlingsreformen har påbudt kommunene å tilby akutte døgnopphold (3). Ordningen synes faglig svakt fundert $(4,5)$.

Studerer man Lillebo og medarbeideres originalpublikasjon (2), fremkommer en del forhold som gjør fortolkningen usikker.

For det første ble studiens registreringsskjema bare utfylt ved $37 \%$ av pasientkontaktene i registreringsperioden. Siden det klart fremgikk av skjemaet at formålet var å registrere innleggelser som kunne vært unngått, er det nokså sannsynlig at det er oppstått en skjevhet ved at legevaktlegene har husket på skjemaet akkurat i de tilfellene der han eller hun mente innleggelsen kunne vært unngått - og at de var mer tilbøyelig til å glemme det ellers. Denne systematiske feilkilden er så stor at resultatene som presenteres, trolig ikke er gyldige.

For det andre sto to av de 18 legevaktlegene som leverte registreringer for hele $48 \%$ av registreringene. Disse to vurderte en mye høyere andel av innleggelsene som unngåelige (hhv. $33 \%$ og $25 \%$ ), sammenliknet med resten av legevaktlegene (14\%). To leger med mye legevaktarbeid og et generelt negativt syn på nytten av innleggelse påvirker altså resultatet $\mathrm{i}$ betydelig grad.

For det tredje kunne forfatterne ha undersøkt hva som viste seg å feile de pasientene som ble antatt ikke å ha nytte av sykehusoppholdet. Det ville vært enkelt, all den stund de jo faktisk ble innlagt. Dette har forfatterne ikke gjort, og i originalpublikasjonen (2) fremhever de det som et fortrinn sammenliknet med studier der man $i$ ettertid har vurdert om innleggelsene faktisk var unødvendige. Dette vitner om en nokså forbløffende grad av freidighet. Det er tidligere vist at forsøk på å sortere ut unødvendige innleggelser på grunnlag av den kunnskapen man har på innleggelsestidspunktet er vanskelig og lett vil føre til betydelig helsetap for pasientene (6).

Lillebo og medarbeideres arbeid er svært politisk korrekt og vil trolig bli omfavnet av representanter for Helse- og omsorgsdepartementet. Men god vitenskap er det ikke.

\section{Det forskes for lite!}

I Tidsskriftet nr. 21/2012 hevder Dag Bratlid \& Thor Willy Ruud Hansen at det brukes for mye ressurser på doktorgrader og at nytteeffekten for samfunnet er for liten til at ordningen kan opprettholdes (1). Jeg vil i det følgende tillate meg å komme med en motmelding:

Det er faktisk lovpålagt for medisinske fakulteter og store sykehus å drive forskning. Den viktigste årsaken til at antall avhandlinger årlig nå er oppe i 396 er omleggingen som ble gjort for noen år siden. Obligatoriske kurs inngår nå som en del av graden, og de kvalitative og kvantitative krav til forskningen er blitt redusert. Intensjonen ved omleggingen var å få spredt forskningskompetansen til flere miljøer.

De fleste begynner på graden i eller rett etter studiet, de færreste med økt status som mål. Til det er statusøkningen for liten, arbeidet for hardt og lønnen under forskningsperioden og lønnsbonusen etter endt disputas altfor lav. Langt de fleste begynner med et ønske om fordypning i et bestemt problem eller fordi de gjerne vil bli bedre skikket til å møte nye utfordringer fremover.

Selvfølgelig skal ikke alle som har tatt doktorgraden forske videre. Et flertall av mine doktorander med klinisk bakgrunn har hatt som målsetting å gå tilbake til klinikken. I min naivitet har jeg trodd på verdien av å ha klinikere med forskningserfaring, kritisk sans og kunnskaper slik at de både skal kunne initiere forskning og etterpå implementere nye behandlingsmetoder i klinikken.

De to professorene påpeker at det er sløseri å utdanne 400 bakere om man bare trenger 40 . Uten å elte den deigen for mye vil jeg påpeke at det ikke er gitt hvem som er den gode bakeren - og langt vanskeligere er det å vite hvem som er den beste konditoren. Fremtidens medisin blir mer og mer høyspesialisert, og for å være med i denne utviklingen trengs det leger med stor kompetanse. Leger som kan og vil lese forskningsartikler. Den nordiske modellen med leger som både er cand.med. og ph.d. er en styrke som andre misunner oss. Jeg er meget usikker på om fordypning og selvstudier er en farbar erstatning. Selvfølgelig kan vi satse på import, slik vi nå gjør med bakervarer, men da må vi spørre oss om det er det vi vil.

I Norge er både de offentlige og de private bidrag til forskningen langt mindre enn $i$ de landene vi vanligvis sammenlikner oss med. Til tross for det greier våre fakulteter å få frem så mange kandidater. Det forskes ikke for mye innen norsk medisin - heller for lite. 